УДК 81'42

ББК 81

DOI: https://doi.org/10.17308/lic.2020.2/2854

\title{
ЯЗЫК КАК ОТЕЧЕСТВО
}

(Рец. на кн.: Турнсек $А$. Путешествия в произведениях Генриха Гейне и Курта Тухольского. Чужая родина. Родная чужбина. Язык как отечество. Дюссельдорф, 2014. 296 с.)

\section{Л. И. Гришаева}

\section{Воронежский государственный университет}

\section{LANGUAGE AS THE MOTHERLAND}

(Reivew of Turnsek A. Reisen in den Werken von Heinrich Heine und Kurt Tucholsky. Fremde Heimat. Heimatliche Fremde. Sprache als Heimat. Düsseldorf : Grupello Verlag, 2014. 296 s.)

\author{
L. I. Grishaeva \\ Voronezh State University
}

Пожалуй, на сегодняшний день не так много найдется исследований художественных произведений, в которых сознательно в фокус обсуждения ставится вопрос о связи личностной идентичности человека, эстетического самоопределения художника, его родного языка и культуры. Рецензируемая книга Андреаса Турнсека принадлежит к таким изданиям, и точка зрения автора недвусмысленно обозначается на оборотной стороне обложки: под портретами Курта Тухольского и Генриха Гейне помещается в лаконичной форме квинтэссенция размышлений: «Возрастающее отчуждение от родины приводит их на чужбину. Для Гейне и Тухольского пушествие - это метафора их личностного прорыва, путешествие подводит их к политическим и поэтическим размышлениям. В путешествии язык для них - родина, когда язык дает им - изгнанным и лишенным гражданства - в пути кров» / "Eine zunehmende Entfremdung der Heimat führt sie in die Fremde. Bei Heine und Tucholsky ist die Reise Metapher des persönlichen Aufbruchs und führt zu politischen und poetischen Betrachtungen. Die Sprache ist auf Reisen ihre Heimat, die ihnen - exiliert und ausgebürgert - unterwegs ein Zuhause gibt".

Мысль о связи путешествия и языка выражается не только в самой книге, она сообщается потенциальному читателю сразу же не только собственно названием, но и иными способами - картинкой на обложке, изображающей непривычный для носителя не- мецкой культуры пейзаж, эпиграфами, представленными выдержками из произведений Генриха Гейне ("In der Fremde"), Курта Тухольского ("Start") и Вильгельма Гёссманна ("Landschaft und Kultur als Lebenserfahrung") на первой странице самой книги, а также названиями глав и разделов, составляющими оглавление. Так, первая часть называется «Fremde Heimat / Чужая родина» (с. 14-36), вторая «Heimatliche Fremde / Родная чужбина» (с. 37-91), третья - «Literarisierung der Reise / Путешествие как литература» (с. 93-140), четвертая - «Unbekannte Stadt - Heimische See. Fremdes Land - Ersehntes Ziel / Heизвестный город - родное море. Чужая страна - желанная цель» (с. 141-269).

Мотив «язык» варьируется в рецензируемой книге многократно и всякий раз по-разному. Достаточно привести в качестве примера только заголовки разделов и параграфов; так, четвертая глава в первой части называется "Muttersprache" / «Родной язык», которая имеет три параграфа: "Deutsch" / «Немецкий язык», "Dialekt" / «Диалект», "Fremde Muttersprache: Französisch" / «Чужой родной язык: французский». Один из параграфов в четвертой главе четвертой части получает название "Fremde Sprache" / «Иностранный язык», а второй раздел в пятой главе четвертой части - "Sprachbarrieren und Problematisierung statt Poetisierung der Fremde" / «Языковой барьер и проблематизация вместо поэтизации чужбины». Кро-

(С) Гришаева Л. И., 2020

Контент доступен под лицензией Creative Commons Attribution 4.0 License.

The content is available under Creative Commons Attribution 4.0 License. 
ме того, раздел "Stilistische Innovationen” / «Стилистические инновации» встречается дважды, сначала при анализе "Die Harzreise" / «Путешествия по Гарцу» Генриха Гейне (c. 46-49), а затем - "Ein Pyrenäenbuch" / «Книга о Пиренеях» Курта Тухольского (с. 64-69). Внимания заслуживает и то, что А. Турнсек практически полностью дублирует логику анализа названных произведений: в этих главах по пять параграфов: "Stilistische Innovationen” / «Стилистические инновации» (с. 46-49 и с. 64-69) - “Ästhetisierung von Natur und Landschaft” / «Эстетизация природы и ландшафта» (c. 49-53), "Foto- und Filmästhetik in Landschaftsund Stadtbildern” / «Эстетика фотографии и кино в изображениях ландшафта и городских ландшафтов» (c. 69-75), "Landschaftstümmelei und Entmystifizierung der Landschaft" / «пафосное воспевание и демифилогизация ландшафта» (с. 53-57) и “Landschaftstümelei und Entmystifizierung der Natur" / «Пафосное воспевание ландшафта и демифилогизация природы» (c. 75-80), "Reiseromantik - Gesellschafts- und Sozialkritik” / «Романтика путешествий - социальная критика и критика общества» (с. 58-62 и с. 80-82), "Begleiter und Begegnungen" / «Попутчики и встречи» (c. 62-64 и с. $82-86$ ).

Логика параллелизма мотивов в творчестве и целей путешествий у обоих писателей выдерживается на всем протяжении произведений, перекличка в тематике, творческой манере, в выборе излюбленных стилистических приемов выдерживается на протяжении всего исследования, что, конечно же, вписывается в традиции литературоведческих штудий. Однако А. Турнсек идет дальше, специально обращая внимание и на закономерности аккультурации, т. е. на процессы, сопровождающие «врастание» человека в инокультурную среду. И это очевидно также из заголовков: в четвертой главе четвертой части есть параграфы с заглавиями “Ankunft - Anfang einer Abneigung” / «Прибытие - начало антипатии» (с. 173-175), "Aufenthalt - Sozialkritik und Geldnot" / «Пребывание - социальная критика и нехватка денег» (с. 175-178), "Abkehr: Rastlose Reise und Heimweh nach fremder Heimat” / «Антипатия: путешествие без остановок и ностальгия по чужой родине» (с. 178-182), которые практически дословно повторяют трактовку такого сложного явления, как культурный шок, а также обозначения отдельных фаз культурного шока. И добавление нового ракурса рассмотрения творчества способствует уточнению представлений о творчестве обоих писателей, позволяя исследователю выявлять новые грани творчества, новые мотивы для произведений, предлагать новое обоснование действий писателей, осмыслять их устремления, надежды и чаяния.

Как рецензенту мне не хотелось бы вмешиваться в процесс знакомства читателя с содержанием и влиять на формирование установки на чтение своим мнением, ведь чтение - это интимный и сугубо индивидуальный и индивидуалистический процесс. Но тому есть еще одна причина: специалисты-литературоведы хорошо знают биографию и творчество и Гейне, и Тухольского, более того, имеют устоявшиеся представления как о личности каждого из художников, так и об их творчестве. Поэтому читателям, решившимся на путешествие по новому и нетрадиционному во всех смыслах жизнеописанию Гейне и Тухольского, самим будет интересно узнать новые факты из биографии обоих писателей и новые интерпретации творчества и намерений их как творцов многочисленных разножанровых произведений. Тем более что степень новизны сведений о жизни и творчестве названных писателей для каждого из читателей будет своя. Это, убеждена, относится, как к носителям русской и иной языковых культур, так и - как это ни покажется странным - к носителям немецкой культуры.

Нельзя не обратить внимание на необычность ракурса анализа, на стремление связать воедино психологические, социологические, антропологические, культурологические и сугубо языковедческие аспекты, так или иначе нашедшие отражение в творчестве обоих писателей. Это позволяет А. Турнсеку как минимум изменить укоренившийся за многие десятилетия взгляд на осмысление творчества обоих художников и тем самым заметить характеристики, ранее выпадавшие из наблюдений литературоведов и историков. Так, во введении А. Турнсек подчеркивает: «В путешествии и литературно-поэтических рефлексиях своих путешествий Гейне и Тухольский выступают как странники, странствующие между мирами: становятся посредниками между прежним и новым опытом, который они приобретают в неизвестном мире» (с. 12).

Но более всего привлекают в рецензируемой книге рассуждения автора о том, как трепетно относятся оба писателя к родному языку, который для них становится в инокультурном окружении отечеством, дарящим в сложнейших ситуациях спокойствие, уверенность, тихую радость, вдохновение, стойкость духа под ударами судьбы. С определенной долей натяжки можно даже сказать, что после знакомства с этой книгой понимаешь буквально, в чем заключается социальная власть языка, о которой так ярко и убедительно говорил в свое время Р. Блакар.

Также нельзя не отметить, насколько разнообразным, гибким, ярким, сочным, образным, точным и пластичным является язык, которым написана рецензируемая книга. Поэтому перед глазами читателя ненавязчиво встают ландшафты, о которых автор книги ведет свой рассказ, раскрывая при этом в том числе и мотивы поступков Гейне или Тухольского, приведших их в соответствующее место в той или 
иной стране, зарождение замысла нового художественного произведения. Это объясняет силу впечатлений, оказанных на Гейне и Тухольского путешествиями, в результате которых появлялись остроумные и содержательные книги, ставшие событиями не только в Германии, но и в других культурах, а также публицистические статьи. А поскольку оба писателя были активными и заинтересованными путешественниками, читатель получает в процессе чтения книги в качестве своего рода бонуса к специальным литературоведческим, лингвистическим и историческим сведениям разнообразные знания из психологии, социологии, культурологии. Важно при этом отметить, что сопоставление биографических фактов обоих художников, творивших в принципиально разные эпохи, но соприкасавшихся с деятелями, оказавшими серьезное влияние на развитие исторических процессов, и бывших не только свидетелями, но и порой активными участниками исторически значимых событий XIX и XX вв., вскрывает интереснейшие параллели в творческом методе Генриха Гейне и Курта Тухольского, в их выборе стилистических приемов, в проработке той или иной тематики.

Манера повествования автора рецензируемого исследования поэтому вполне созвучна названию книги и ее внутреннему содержательному стрежню - язык как родина, язык как дом на чужбине и в путешествиях, потому что и сама жизнь, если верить известной концептуальное метафоре, - путешествие. Одним из излюбленных приемов автора книги является членение сложных слов, благодаря чему смысл высказывания существенно обогащается многочисленными нюансами, ср.: "Heine und Tucholsky haben beide im Gepäck diese Kombination aus Reise-Lust, Schreib-Wut und Neu-Gier. Es sind Kosmopoliten, die sich aufmachen. Sie mißbilligen jeglichen Nationalismus und hegen höchstens Lokal-Patriotismus - und auch den mindestens augenzwinkernd. Auch Fern-Weh und SehnSucht nach neuen Eindrücken, internationalen Impulsen, fremden Inspirationen lassen sie aufbrechen” («В багаже у Гейне и Тухольского комбинация из любви к путешествиям, страсти к писательству, мании новизны. Это космополиты, отправляющиеся в дорогу. Они против всякого национализма и проповедуют в лучшем случае локальный патриотизм - и его-то по крайней мере с подмигиванием собеседнику. Тоска по далеким странам, страстное желание новых впечатлений, международных импульсов, неизведанных еще вдохновений побуждают их отправляться в путь») (c. 13).

Повествование богато и разнообразно иллюстрировано: это репродукции картин, портретов, копии почтовых карточек, фотографий, документов. Важно отметить, что в книге общим достоянием становятся в том числе и изображения обоих художников, ранее не публиковавшиеся и предоставленные автору книги из своих архивов. Тем самым знания о жизни и творчестве обоих немецких художников пополняются не только через анализ, традиционный для филологов, но и благодаря публикации разнородной информации, имеющей то или иное отношение к творчеству Гейне и Тухольского.

Для читателя книги важно знать, что в книге цитируются как широко известные произведения, так и мало известные не только широкой публике, но даже и специалистам.

Характерно, что А. Турнсек мастерски вплетает рассуждения Генриха Гейне и Курта Тухольского в свое исследование, т. е. цитаты из их произведений, предоставляя читателю своей книги убедиться в справедливости суждений относительно наблюдений над художественными и публицистическими произведениями анализируемых авторов и их мировоззрением. Так, заключительные размышления в книге А. Турнсек начинает с довольно обширной цитаты одного из повествований Курта Тухольского, из которой становится ясным, что литературное путешествие - это самопознание и что, согласно Генриху Гейне, «каждый поэт по своей природе - космополит» (с. 270). Поэтому одним из резюмирующих тезисов является следующее утверждение: «Гейне и Тухольский объединяют эмфатическую субъективность и критическую абстракцию в качестве взаимодополняющих компонентов в литературное посредничество путешествия» (с. 270).

А. Турнсек называет такие общие стилистики характеристики обоих художников, как демонстративное дистанцирование, стремление не скрываться за стереотипами, а просто описывать страны, ландшафты, людей и их ментальность, неопределенность, сопровождающая путь путешественника, а также предельная точность при описании политических и социально-критических аспектов. Оба обращают внимание на следы предшествующих литературных эпох, не дублируя их, а расставляя своего рода указатели, направляющие путешествие по новым маршрутам. Оба художника исключают экзотику, равно как и малоинформативные статистические данные и имеющие хождение рассказы, типичные для туристических проспектов для образованной публики (с. 270).

Эстетизация и персонификация природы - типичные стилистические особенности творчества обоих писателей, хотя воплощаются они по-разному. Если Тухольский демонстрирует скепсис по отношению к символизму ландшафта, то Гейне иронизирует, если подходит к границам идеализации. Оба отклоняются от манеры видеть в природе и пейзажах метафорические декорации (с. 270-271).

Оба переходят через границы в буквальном и литературном смысле, и даже когда вынуждены эми- 
грировать, они не отрекаются от своего патриотизма «без флагов и войск» / "Patriotismus - ohne Fahnen und Truppen” (c. 272). Родины для Тухольского довольно для того, чтобы поставить ноги под стол, на котором он пишет в Германии и о Германии, Франции или Швеции (с. 272). И Турнсек цитирует Гейне, написавшего прилежным националистам, как он любит своею родину (с. 272). Поэтому «путешествие для них - это сознательное прекращение нормального течения жизни, которое обретает рисунок только на чужбине. Однако для обоих путешествие сопровождается эскапистской попыткой личностного прорыва» / "Die Reise ist bewußte Unterbrechung des normalen Lebensflusses, der nun in fremden Bahnen mäandern kann. Für beide sind Reisen aber auch verknüpft mit dem eskapistischen Versuch eines persönlichen Aufbruchs" (c. 272).

Открытость миру и отсутствие укорененности предоставляют Генриху Гейне и Курту Тухольскому - каждому в свое время - необычную способность восприятия во время путешествий, превращающуюся в стилистические инновации в их литературном творчестве (с. 272). Родина отдаляется от них, становится чужой, а чужбина раскрывается им и другим как родина, язык есть и будет для них родиной, несмотря на то, или благодаря тому, что они в пути на свою родину (с. 272).

Воронежский государственный университет Гришаева Л. И., доктор филологических наук, профессор кафедры немецкой филологии

E-mail: grishaeva@rgph.ru

Поступила в редакциюю 5 февраля 2020 г.

Принята к публикации 25 марта 2020 г.

\section{Для цитирования:}

Гришаева Л. И. Язык как отечество (Рец. на кн.: Турнсек $A$. Путешествия в произведениях Генриха Гейне и Курта Тухольского. Чужая родина. Родная чужбина. Язык как отечество. Дюссельдорф, 2014. 296 с.) // Вестник Воронежского государственного университета. Серия: Лингвистика и межкультурная коммуникация. 2020. № 2. C. 152-155. DOI: https://doi.org/10.17308/ lic. $2020.2 / 2854$
Исследование Андреаса Турнсека завершается цитатой из Курта Тухольского (впрочем, автор рецензируемой книги 1059 раз цитирует как обоих писателей, так и других исследователей, о чем свидетельствует список примечаний): «Путешествия. Путешествия. Шлифовать корни, бледные, тонкие нити, которые так любят пить и искать почву, которая им по вкусу. Каждый человек ищет свою землю» / "Reisen. Reisen. Die Wurzeln schleifen, blasse, dünne Fäden, die so gern trinken wollen und einen Boden suchen, der ihnen schmeckt. Jeder Mann seine eigene Erde" (c. 272).

Размышляя над вопросом, кого могла бы заинтересовать книга Андреаса Турнсека, нельзя не признать широту круга потенциальных читателей: это литературоведы, историки, культурологи, лингвисты, краеведы, философы, а также почитатели творчества Генриха Гейне и Курта Тухольского. Длина перечня потенциальных адресатов обусловлена широтой охвата проблематики, обсуждаемой А. Турнсеком.

Хотелось бы обратить внимание и на сугубо перцептивные и в первую очередь тактильные ощущения от издания: шрифт легко читается и не раздражает, бумага высокого качества, формат очень удобен для того, чтобы держать довольно длительное время книгу в руках. Поэтому чтение книги доставляет не только интеллектуальное, но и эстетическое удовольствие.

Voronezh State University

Grishaeva L. I., Doctor of Philology, Professor of the German Philology Department

E-mail: grishaeva@rgph.ru

Received: 5 February 2020

Accepted: 25 March 2020

\section{For citation:}

Grishaeva L. I. Language as the Monherland (Reivew of Turnsek A. Reisen in der Werken von Heinrich Heine und Kurt Tucholsky. Fremde Heimat. Heimatliche Fremde. Sprache als Heimat. Düsseldorf : Grupello Verlag, 2014. 296 S.) Proceedings of Voronezh State University. Series: Linguistics and Intercultural Communication. 2020. No. 2. Pp. 152-155. DOI: https://doi.org/10.17308/lic.2020.2/2854 